\title{
ILLUSTRATED KEY TO THE GENERA OF FAIMILY ANACARDIACEAE IN PUNE AND ADJOINING REGION
}

KEY WORDS: Illustrated Key, Family Anacardiaceae , Pune And Adjoining Region

\section{Ashok M. Patole*}

Associate Professor ,Department of Botany, Abasaheb Garware College, Pune 4 *Corresponding Author

Everyone including the specialist, knows that a good Illustration is far superior and more efficient in recognizing plants than lengthy descriptions, or even keys. In the recent years there has been growing interest in plant diversity studies in general and floristic studies in particular Illustrations of plants are as old as human civilization and yet, there is ever greater need for good Illustration. The present work is a sincere attempt to provide an illustrative key to the genera of family Anacardiaceae Method includes , field study ,herbarium study \& Illustrations based on plant specimens. Besides the time consuming process of correct identification of plant species can be minimized, if such flora is easily accessible available at the nearest reference point.

\section{INTRODUCTION :}

In the recent years there has been growing interest in plant diversity studies in general and floristic studies in particular. In this connection regional floristic studies are of much importance. ${ }^{1}$ It can be achieved by intensive exploration of smaller areas. Method includes, Field study, Herbarium study \& Illustrations based on plant specimens. Besides the time consuming process of correct identification of plant species can be minimized, if such flora is easily accessible available at the nearest reference point. Such attempts have been made by taxonomists and other botanists in various research institutes and teachers in degree colleges. Illustrations of plants are as old as human civilization and yet there is ever greater need for good illustrations. Everyone including the specialists knows that a good illustrations is far superior and more efficient in identification of plants than lenthy descriptions or even keys , $^{2,3}$

In our study we have described illustrated key to genera of Family Anacardiaceae There is stray floristic work on various talukas of Pune district. These floristic works i.e. the floras or check lists, very rarely provide illustrations, 1-2 which is a easy mode of comparing, verifying and identification plants. The present work is a sincere attempt to provide an illustrative key to species depicting important morphological characters to identify the plants easily to give structural details and discriminate the characters of taxonomic importance to identify the plant as they are having different medicinal uses and economic values. 4, 5 The present work is based on the results of about intensive exploration of genera of family Anacardiaceae in pune and adjoining region .

\section{MATERIALS AND METHOD}

The present works is based on the result of intensive explorations to study the genera of family Anacardiaceae in pune and adjoining region .

in pune and adjoining region.The study was undertaken by Field study , Herbarium study, Illustrations based on plant specimens. Pune and adjoining regions mentioned as above is approachable by own vehicle during all seasons. A major bulk plants of collected in rainy seasons because majority of the flowering plants found in rainy reasons and especially some ephemeral plants are only found in monsoon period.

While collecting the specimens, the data such as habit, habitat, flower colours, fragrance if present, frequency of distribution, local names and uses, if any were recorded in the field itself. Besides the wild species, some cultivated plants, weeds of cultivated field and road sides have also be collected. These specimens collected were pressed in the field using blotting paper and old newspaper. The flowers of some of the species which were of some botanical interest were fixed in $4 \%$ formalin for further studies in the laboratory. ${ }^{6}$ These specimens have been deposited in the herbarium of University of Pune, Department of Botany, Pune-411 007. Generally 3-4 specimens of the each plant were collected. Two specimens were mounted and others were treated as duplicate specimens.

Preparation of Herbarium sheets was done carefully collected taking care that the specimens are healthy, free from evidence of insect feeding, rust infections, and other obvious pathological symptoms. It was ensured that the specimen is either in flowering or fruiting condition. The specimen is herbaceous, always include enough of the underground parts to show their characters.

The plant specimens pressed on the spot and some time collected in vasculum and pressed after coming to laboratory. While collecting the specimens, the data such as habit, habitat, locality, local name, etc. have been immediately recorded in the field diary. After returning to the laboratory, the plant specimen have been pressed in between the sheets of blotting paper. One plant should be arranged, on one sheet in a manner that there should be no over lapping of parts. The large size specimens have been folded in ' $\mathrm{V}$ ', ' $\mathrm{Z}$ ', 'W' ' $\mathrm{C}$ ' shape. The blotting papers with plant specimens have been placed in field press for about 24 to $48 \mathrm{hrs}$. The press is then opened, blottings have been changed and rearranged the plant specimen properly. This practice made continuous for 10 to 15 days till the specimens get properly dried.

Poisoning of the specimen have been done immediately after collection; all the specimens were poisoned in aqueous solution of Mercuric chloride and dried using standard herbarium techniques. After drying, the specimens were mounted for permanent record on herbarium sheets. The herbarium sheets of standard size $42 \mathrm{~cm} \mathrm{X} 28 \mathrm{~cm}$; and such standard herbarium sheets have been used. The specimens were mounted on the sheets with the help of glue or by stitched wherever necessary with help of cotton thread. ${ }^{8}$

The plant specimens have been tentatively identified in the field and identification was confirmed by using different floras. The important floras such as "Flora of presidency of Bombay" by Theodore Cooke (1958), ",4 "Flora of British India" (1872 to 1897 ) by J.D. Hooker ", "Flora of Presidency Madras" (Gamble, 1957) "6lora of Akola District, Maharashtra" by S.Y. Kamble and S.G.Pradhan ( 1988) ${ }^{7}$,"Flora of Maharashtra state" (2000) by N. P. Singh ${ }^{8} \&$ S. Karthikeyan Flora of Mahabaleshwar and adjoins, by Deshpande (1995 ) " "Flora of Nasik" by Lakshminarsimhan (1991) "10 "Flora of Raigad by Kothari and Moorthy (1993) ${ }^{11}$ The cultivated species were also identified with the help of Manual of Cultivated Plants by Bailey (1949). ${ }^{2}$ Then again the specimens confirmed by matching with authentically identified

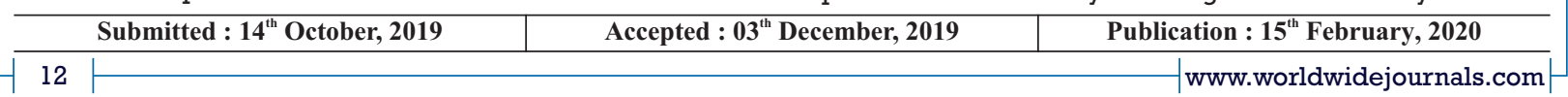


specimens deposited in the herbarium of Botanical Survey of India,Western Circle Pune.

\section{METHODOLOGY OF ILLUSTRATIONS}

The main purpose was A depiction of the habit, alongwith finer structural details especially of flower and fruit in a comparable format. Thus the details depicted are taxonomically significant. Following the general pattern of one plate per species, the first step was to visualize the number of sketches involved and scale suitable to the illustration i.e. reduction of larger organ and enlargement of smaller ones.

Depiction of the twig as visual aid to recall the plant characters is important. Thus special efforts were made to make the habit sketch and dissections from the same specimen in order to avoid errors.

A photograph of the specimen from the same collection was most useful in rounding off the habit sketch. To satisfy this purpose an extensive field work was carried out in the study area in various seasons to capture the flowering and fruiting season of plants.

The plant parts were detached from the twig, and examined under a binocular dissection microscope under suitable magnification ( X5 or X10 is usually sufficient). Almost all the details were studied. Serial sketching of structure in order (Calyx, Corolla, Androecium, Gynoecium, Fruit ) with detail was done. All the sketches were drawn with fresh specimen and with hand by using isograph drawing pens with zeichentusche drawing ink on A4 size bond paper and scanned for further DTP work in Photoshop, then it was inserted is MS- word and edited for labeling, numbering and preparation of keys. The sketches were made first with pencil, with suitable scale (X 5) in case of minute flowers the magnification was X2- X20 times of the original specimen. In case of large specimen five to twenty times reduction was done. All the sketches are calibrated and suitable magnifications have been shown near the sketch. ${ }^{9}$

The advantage of keeping the same scale of magnification/ reduction for comparable structure within the taxon or for all the species enables us to emphasize the actual scale of various plant parts.

From the printed plate, which usually gets reduced in size during DTP or printing it is possible to compute back the original values, both of the sketch and the actual material. The sketches aim to convey maximum information for which all parts are illustrated : habit, flower, calyx, corolla, stamen (front and back view), pistil, ovary (V.S. and T.S. ), fruit and seeds. Scale is individually given to all figures.

Genera of family Anacardiaceae in Pune and adjoining region was arranged in the modified Bentham and Hookers system of classification, followed in India. Within genera the species are given in alphabetical order. An index gives the names of families genera and species as well as vernacular names. ${ }^{10}$

The discriminating morphological character is placed below the description in form of the actual sketch of the selected character in the indented key e.g leaves, stamens, flowers,fruits etc. lots of efforts have gone on to this DTP work to prepare the illustrated key. All the sketches here are given with scale, so as to calculate the actual size of the specimen. Finally we have no pretension that this is the last word on this topic. Probably a more extensive explanatory study might reveal more of such variations, even within Maharashtra. The plants described are illustrated, so that even non botanist can know what is what.

\section{RESULTS :}

FAMILY ANACARDIACEAE KEYTO THE GENERA. 1.Leaves simple (Fig. i. a \& b)

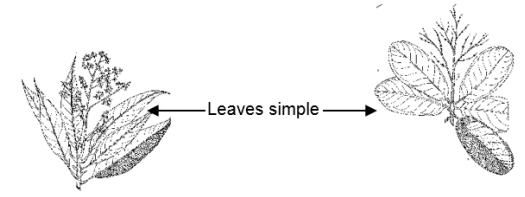

Fig. i.a.Mangifera .indica L.b. Semecarpus anacardium L.

\section{Styles 3 or more (Fig. ii. a) _.. SEMECARPUS}

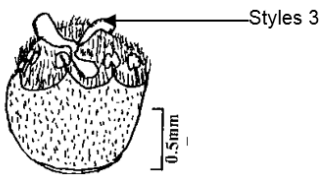

Fig. ii. a. Semecarpus anacardium L. (Female flower)

2. Style single ... MANGIFERA

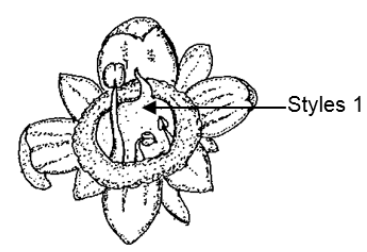

Fig. iii.a. Mangifera indica L. (Flower)

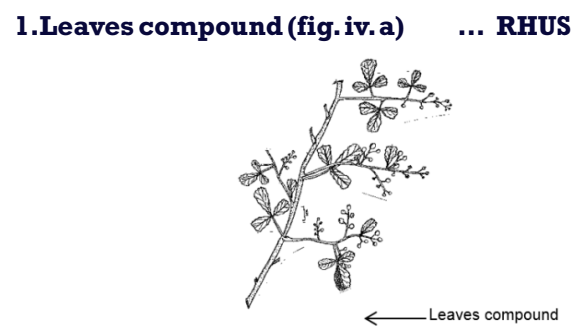

Fig.iv. a. Rhus mysorensis G. Don

\section{DISCUSSION}

This work provides a handy tool to those, who wish to work in the field of taxonomy. The pictorial keys enable the researcher to identify the plants by matching the characters with the illustrations which are drawn with scale. So the confusion generally created while reading the information of plant can be minimized. More extensive keys could have been prepared, but due to time constraint, which may be taken up in near future.

There have been innumerable thesis, research papers, projects going on where many ideas have been expanded, still basic need of floristic study is, correct identification of floristic elements in the field. We as researchers or botanist, get to realize the heavy price we will have to pay in future, if we don't start such work today. These Illustrations are good enough as regard the habit of plant but not for the structural details. These old volumes are scarce, no larger in print and becoming beyond the reach of common research student or college teachers working on floristic.There is also ever greater need for good illustration. ${ }^{10,11}$

Mangifera indica $L$. is large evergreen trees, upto $60 \mathrm{ft}$. high. Leaves oblong or elliptic -lanceolate, $1-25 \times 2.5-8 \mathrm{~cm}$, crowded at the ends of branches, acute, shining ; entire or 
undulate. Petioles $1-6.5 \mathrm{~cm}$ long. Flowers $0.5 \mathrm{~cm}$ across, Inflorescence terminal panicles. Sepals ovate, concave, pubescent outside. Petals $4-5$, free or adnate to disk. Stamens $1-5$, inserted just within disk or on it, usually only one perfect and much longer than other. Staminodes $3-4$, apically glandtipped. Ovary oblique, sessile, l-celled; style lateral. Placentation marginal. Fruits a drupe, $7.5-20 \mathrm{~cm}$ long ,obliquely pyriform or obovoid, stone compressed, fibrous , very hard. Seed oblong. Flowering occurs during January June.Commonly cultivated for edible fruits and also found in wild. Located at Mulshi, Katraj, Khadkwasla, Panshet, Bibwewadi, Pune University campus. ${ }^{12,13}$

Rhus sinuate Thumb is an armed shrubs or small tree, 2.5-3 $\mathrm{m}$ high. Leaves trifoliate; leaflets $1.0-3.5 \times 0.8-1.5 \mathrm{~cm}$. obovate, cuneate, margins sinuate - toothed. Inflorescence in axillary panicles. Flowers $0.15-0.2 \mathrm{~cm}$. across. Calyx - 5, triangular, persistent, pubescent outside, much shorter than the petals. Petals $-2 \mathrm{~mm}$ long, greenish - yellow oblong, subacute, glabrous. Disk 5 - lobed, lobes often notched. Style 3, excentric, connate at the base. Ovary globose, uniocular. Placentation basal. Fruits a drupe, $0.3-0.4 \mathrm{~cm}$ across, subglobose, ripens brown, glabrous, shining. Seeds reniform, yellowish.Flowering at July - December.Common in deciduous forest. Located atVetal hill. ${ }^{12,13}$

Semecarpus anacardium L. is medium sized tree, upto 8-12 $\mathrm{m}$ high. Leaves simple, oblong - elliptic or ovate $20-35$ × 8 -15 $\mathrm{cm}$ thick, rusty - villous below ; apex obtuse, truncate cordate at base; petioles $1.25-4.0 \mathrm{~cm}$ long. Inflorescence in terminal panicales, upto $30 \mathrm{~cm}$ long, hairy. Flowers $0.5-0.6$ $\mathrm{cm}$ across, greenish - yellow. Calyx segment about $1 \mathrm{~mm}$ long, pilose outside. Petals 5-6, imbricate, $4-6 \mathrm{~mm}$ long and $2 \mathrm{~mm}$ broad, acute. Stamens $5-6$ inserted at the base of disk, fertile, imperfect in female flowers. Ovary subglobose, densely pilosed, crowned with 3 styles; ovules anatropous, pendulous. Drupes, smooth, $2.0-3.0 \mathrm{~cm}$ across, yellowish to orange black when ripens, seated on a fleshy receptacle about $1.5 \mathrm{~cm}$ long.Flowering ocures during July-December. C o m m on throughout in deciduous forests. Located at Mulshi, Katraj, Khadkwasla, Panshet, Bibwewadi, Pune University campus. ${ }^{12,13}$

Thus due to different uses of these plants of the same genus it is necessary to correct identify them which is possible with the help of our illustrated keys. This work will provide a practical introduction to the techniques of documentation in taxonomy to study the plant genetic resources. Besides the time consuming process of correct identification of plant species can be minimized, if such flora is easily accessible available at the nearest reference point. Instead of wasting time and paying heavy fees which such institute ask for identification, one can easily go through the illustrative keys and identify the plant, within no time. Therefore such kind of floras are need of time today and in future.

\section{AKNOWLEDGEMENT}

Dr SY Kamble , Dr Shirke DR, Dr,. S D Sathe for proof reading and valuable suggestions

\section{REFERENCES}

1. Cooke T.The Flora of the Presidency of Bomba y vol.I, II, III, London. Reprinted ed.Bot.Surv. India, pp.1958.

2. Baily LH. Mannual of cultivated plants. Me. Millan and Co.New York. 1949.

3. Cooke T. 1901-1908. The Flora of the presidency of Bombay, London. (Rept.ed. 1958-3 vols.).B.S.I. Calcutta.

4. Kamble SY and SG Pradhan. The Flora of Akola district, Maharashtra. Botanical Survey of India, Calcutta. 1988.

5. Singh NP, et all. Flora of Maharashtra state Dicotyledones 2001, 2, Flora of India, Series 2, Botanical survey of India.

6. Bedd IC, Beddome RH. Icones Plantarum Indiae Orientalis, or plates and description of new and rare plants from Southern India and Ceylon. Vol I, Pts. 1-15.1868-1874. (cited as 1874). Madras

7. Kulkarni BG.J Bomb Nat Hist Soc 1973;70 (1):234-238.

8. Deshpande S, BD Sharma \& MP Nayar. Flora of Mahabaleshwar and adjoining, Maharashtra. BSI FI India ser 1995; 3: Pp. 431, pI. 4, f. 38. 1993; vol. Pp. 443-776, pI. 4, f. 18.

9. Agarkar SV \& Jadge DR. Asian J Chem. 1999; 11 (2):295-299.

10. Alam MM, Siddiqui MB and Husain W.Fitoterapia 1990;61 (3):240-242

11. Cooke TJ.Bombay Nat Hist Soc 1987;2: 133-140.
12. Hooker JD.The Flora of British India. 1872-1897, 1-7. London.

13. Ali, Mohammed. Text Book of Pharmacognosy, CBS Publisher \& Distributors, Delhi,pp.8. 